\title{
Seeing Environmental Issues as a Source of Rare Earths
}

\author{
Mateus L. B. Moraes, Ana Claudia Q. Ladeira, Elaine C. Felipe, Thales A. Carneiro, \\ Augusto A. Camargos, Gabriel Silva, Bruna Vidigal, Kelvin A. Batista \\ CDTN - Centro de Desenvolvimento da Tecnologia Nuclear \\ Av. Presidente Antônio Carlos, 6.627, Campus da UFMG, Pampulha, Belo Horizonte, Minas Gerais, Brazil \\ mateus.moraes@cdtn.br; acql@cdtn.br
}

\section{Extended Abstract}

Rare Earth Elements (REE) are one of the most strategical resources and have become the main interest of many developing and developed nations in the past seventy years, and its importance tend to increase further. New technologies demand these elements and some of them are critical, with high demand and limited supplies, amongst them are $\mathrm{Y}, \mathrm{Nd}, \mathrm{Eu}$, Dy and Tb [1], [2]. In the state of Minas Gerais (Brazil), the mining industry plays a crucial role in the economy, whose main products are notably lead, zinc, gold, niobium, and copper. Furthermore, Minas Gerais has strategically important Rare Earth Element (REE) ores, whereas production is still incipient [3]. Acid Mine Drainage (AMD) is a continuous natural leaching process that may contain variable concentrations of REE, it occurs in some sites around the world [4]-[6]. One of these sites is located in a closed uranium mine in Caldas, Minas Gerais, Brazil, where the REE concentrations in AMD are about 130 $\mathrm{mg} \mathrm{L}^{-1}$ [7], [8]. The AMD waters are treated with lime with a maximum flow rate of $300 \mathrm{~m}^{3} \mathrm{~h}^{-1}$, and the neutralization of the waters consumes about $12 \mathrm{t}$ of lime per day and generates enormous amounts of precipitate [9]. The recovery of the RRE can yield in approximately $936 \mathrm{~kg}$ daily. Our research team is studying two ways of recovering the REE present in the AMD waters, using ionic resins and co-precipitation with iron, aluminum and manganese oxihydroxides. Results show that REE can be successfully recovered by both methods with high efficiency. Specifically, the use of a cationic resin in batch experiments can recover up to $90 \%$ of the REE present in the feed solution at $\mathrm{pH}=1.3$. The co-precipitation with aluminum and manganese oxihydroxides at $\mathrm{pH}=8$ can recover up to $95 \%$ of the REE present in a laboratory AMD, producing a solid phase with $\pm 14 \%$ of REE oxides. Further studies focus on optimizing the processes and on concentrating the REE after the recovery, specifically the elution of the resins and the leaching of the precipitates.

\section{References}

[1] D. Bauer, D. Diamond, J. Li, D. Sandalow, P. Telleen, and B. Wanner, "US Department of Energy: Critical Materias1 Strategy, December 2010," Agenda, no. December, pp. 1-166, 2010.

[2] H. Paulick and E. Machacek, "The global rare earth element exploration boom: An analysis of resources outside of China and discussion of development perspectives," Resour. Policy, vol. 52, no. February, pp. 134-153, 2017.

[3] F. E. Lapido-Loureiro and R. L. C. Santos, O Brasil e a reglobalização da indústria das terras raras., vol. 1. 2013.

[4] F. Zhao, Z. Cong, H. Sun, and D. Ren, "The geochemistry of rare earth elements (REE) in acid mine drainage from the Sitai coal mine, Shanxi Province, North China," Int. J. Coal Geol., vol. 70, no. 1-3, pp. 184-192, 2007.

[5] C. Ayora et al., Recovery of Rare Earth Elements and Yttrium from Passive-Remediation Systems of Acid Mine Drainage, vol. 50, no. 15. 2016.

[6] P. L. Verplanck, D. K. Nordstrom, H. E. Taylor, and B. A. Kimball, "Rare earth element partitioning between hydrous ferric oxides and acid mine water during iron oxidation," Appl. Geochemistry, vol. 19, no. 8, pp. 1339-1354, 2004.

[7] M. L. B. Moraes, A. C. Q. Ladeira, and R. Earth, "Recovery of Rare Earth Elements By Co-Precipitation With Iron , Aluminum and Manganese ( Hydr ) Oxides From Acid Mine Drainage," in 2017 Sustainable Industrial Processing Summit and Exibition, vol. 1, pp. 208-220, 2017.

[8] A. F. da S. Gomes and A. C. Q. Ladeira, "Caracterização de lamas contendo urânio como subsídio para ações futuras de mitigação," Rem Rev. Esc. Minas, vol. 64, no. 4, pp. 479-485, 2011.

[9] V. Fonseca, "Mais energia, menos impacto para o ambiente," Publicação trimestral da Fundação de Amparo à Pesquisa do Estado de Minas Gerais - FAPEMIG, N³9 - Set-Nov, p. 62, 2009. 